\title{
A SPATIO-TEMPORAL SYNCHRONIZATION OF PERIODIC MARKETS: EVIDENCE FROM THE HINTERLAND OF AKWA IBOM STATE
}

\section{UDOSEN AND D. ADAMS}

(Received 9, September 2008; Revision Accepted 17, March 2009)

\section{ABSTRACT}

This study seeks to identify the 'rings' of periodic market days in Akwa Ibom State, using eighteen periodic markets as case study The entire landmass of the state was covered with a network of grids. These grids were numbered and a table of random numbers was used in selecting a target population of eighteen communities in the hinterland of the state. The base map of Akwa lbom State at a scale of $1 ; 750,000$ was scanned [and geo-referenced using Erdas Imagine 8.5 software], exported into a GIS environment and digitized using Arcview 3.1. This facilitated the mapping of the spatial distribution of the selected markets. The 'rings of market days' in the study area was also displayed graphically and the results indicate that rural markets appear to have been sequenced in such a way that spatial and temporal competition are rendered complementary. In the study area, the eight -day markets are common [ $56 \%$ of selected markets];4-day(27.5\%);weekly(11\%])and 3-day cycle(5.5\%0. Some of the traditional markets are named after the market days, for instance, Etaha Itam and Obo Annang markets in Itu and Essien Udim LGAs respectively. The rural/traditional markets deal on low order goods and are mainly agricultural produce, hence the numerous periodic markets in rural/suburbs are bulk-building points for agricultural produce [as they supply farm produce to the urban markets]. More importantly, the rural economy is characterized by very low per capita income and weak purchasing power. Market days are usually spaced in time to allow a sufficient build up of effective demand, and sometimes also of supply.

KEYWORDS: periodicity, market days, spatial pattern, threshold and range of goods

\section{INTRODUCTION}

Markets are often in a fixed location, although sometimes the traders have to move around to different locations in order to reach all their customers. Whether they remain fixed or move is a function of the relationship between the maximum range of a good and the threshold demand.[i.e. maximum range is larger or equal to the minimum threshold of a good]. The maximum range of a good is the farthest distance the population is willing to go in order to buy a good offered at a specific place. The minimum threshold of a good is the minimum amount of consumption needed to pay for production or offering of the central good. If the maximum range is larger or equal to the minimum threshold, then the market remains in a fixed location. On the other hand, if the range is smaller than the minimum threshold, the traders are forced to travel to reach their customers. The former is applicable to all the rural markets in the less developed countries, including Nigeria (Bromley, 1971; Ekong, 2004; Hay,, 1971; Hodder, 1961; Mckim, 1972 and Scott, 1972). This is because the rural/traditional markets deal on low order goods and are mainly agricultural produce, hence the numerous periodic markets in rural/suburbs are bulk-building points for agricultural produce (as they supply farm produce to the urban markets). More importantly, the rural economy is characterized by very low per capita income and weak purchasing power (Filani and Richards,1976; Skinner,1964; Stine,1962 and Webber and Skymanski, 1973). Market days are

C. Udosen, Department of Geography and Regional Planning University of Uyo, Akwa Ibom State, Nigeria

D. Adams, Department of Political Science University of Uyo, Akwa Ibom State Nigeria 
usually spaced in time to allow a sufficient build up of effective demand, and sometimes also of supply for instance of fresh vegetable leaves such as Afang or Atama. Often temporal periodicity alone cannot guarantee the minimum threshold required to sustain each market. There is, therefore the need for spatial periodicity among the traditional markets to minimize competition for available consumer demand in space and time. Rural markets appear to have been sequenced in such a way that spatial and temporal competition are rendered complementary[Nwafor, 1982 ]. In this direction, this study seeks to ascertain the periodicity of traditional markets in Akwa Ibom State.

\section{Aim and Objectives}

The main aim of the study is to identify the 'rings' of periodic market days in Akwa Ibom State, using eighteen periodic markets as case study

The specific objectives include the following;

- identify and characterize the traditional markets, market days and movement of itinerant traders between these periodic market

- show the spatial distribution of the sampled periodic markets in the state

- $\quad$ identify and map the spatial and temporal pattern of market periodicity in the study area and

- $\quad$ ascertain the origin of periodic markets in the state

\section{MATERIALS AND METHODS Study area}

Akwa lbom State is situated between latitudes $4^{\circ} 30^{1}$ and $5^{\circ} 30^{1} \mathrm{~N}$ and longitudes $7^{\circ} 30^{1}$ and $8^{\circ} 20^{1}$ E.[Fig.1] The state is characterized by two seasons, the wet or rainy season which lasts for about 9 to 10 months and a short dry season during which the state is covered by dry and dusty harmattan winds. Rainfall is heavy ranging from over $3000 \mathrm{~mm}$ along the coast to $2,000 \mathrm{~mm}$ on the northern fringe. Temperatures are uniformly high throughout the year with slight variation between 27 and $29^{\circ} \mathrm{C}$. High relative humidity values of $60-$ $90 \%$ are common.

The above climatic factors favour luxuriant tropical rainforest and cultivation of mainly trees, root crops and a few grains such as oil palm, cassava, maize, swamp rice in the north, okro, fruited pumpkin, cocoyam amongst others.

Akwa Ibom State is reputed to hold the highest oil palm trees per capita in Nigeria. These crops/fruits are most times taken to the rural markets by the farmers on market days. It contains one of the densest rural populations in the country with about $70 \%$ of its labour force engaged in peasant agriculture. River-deposited sands and clays cover over 80 percent of the state and constitute the Benin Formation, sometimes called the Coastal Plains Sands. The sandy soils formed from this formation are not only acidic but very low in basic cationic nutrients, hence the fertility depends on built-up of organic matter. [Udosen,2008] On the other hand, the soils found in the adjoining stateCross River developed from the nutrient rich Precambrian basement complex rocks, particularly around Ogoja and Obudu and are more fertile. Thus, the bulk of food supply in the thickly populated rural settlements and clusters of urban centres in Akwa lbom is sourced from Cross River State and supplemented with surplus agricultural produce by the individual peasant farmers in Akwa Ibom State. 


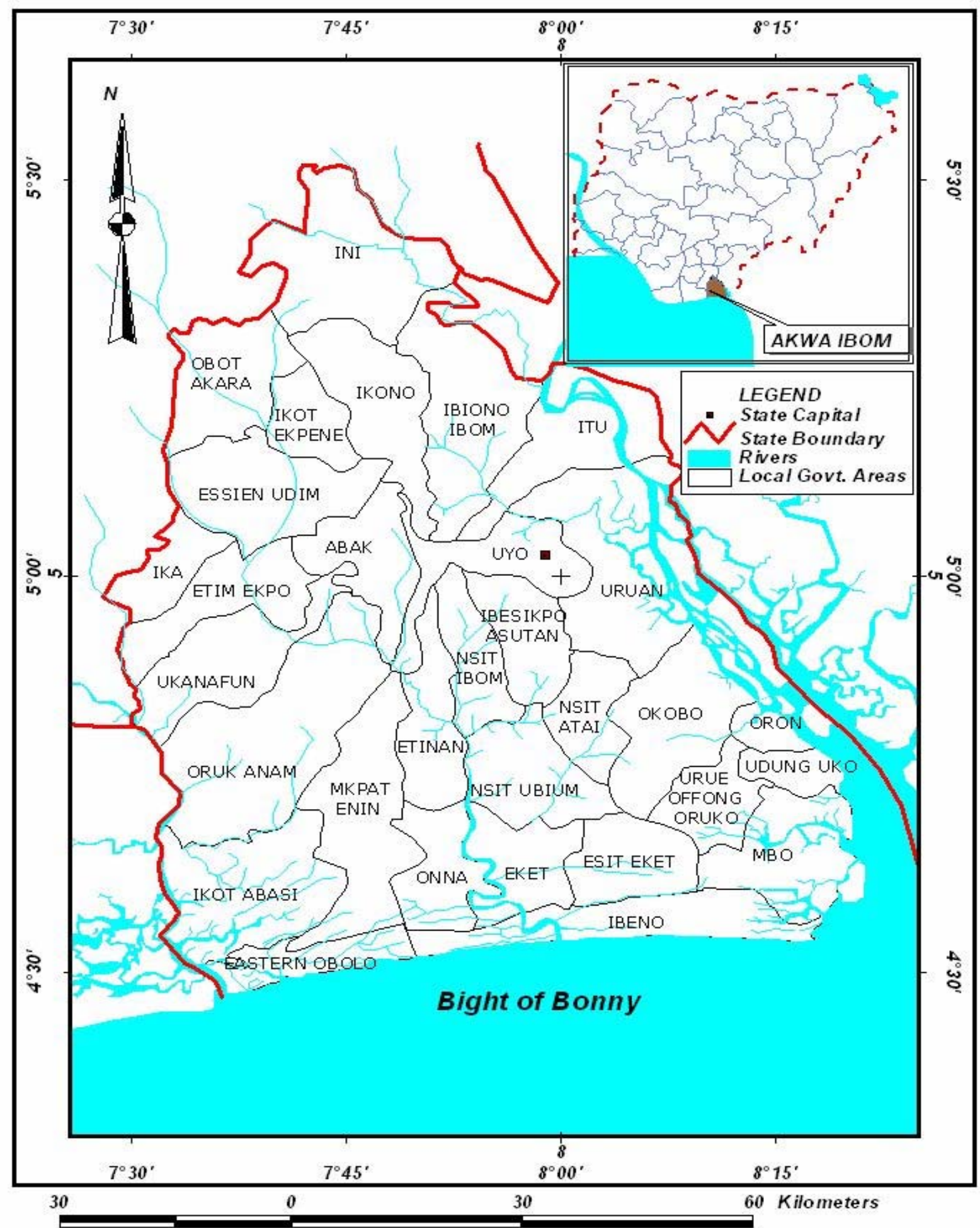

FIGURE 1: THE STUDY AREA 


\section{Data Collection}

A random survey of eighteen periodic markets was carried out. From these selected markets, focus group discussions, field survey/documentation as well as administration of a well structured questionnaire interview was done. Fieldwork for this study was carried out in May 2008 and involved discussion through open interviews with itinerant traders and market officials of both consumer items and services rendered in each of the markets.

Information derived from this source was backed up by 300 questionaire interviews which included a 5 percent sample of all the traders. Primary data were backed up by information derived from previous studies and relevant literature.

The entire landmass of the state was covered with a network of grids. These grids were numbered and a table of random numbers was used in selecting a target population of eighteen communities in the hinterland of the state.

\section{Data analysis}

The base map of Akwa lbom State at a scale of $1 ; 750,000$ was scanned [and georeferenced using Erdas Imagine 8.5 software], exported into a GIS environment and digitized using Arcview 3.1.This facilitated the mapping of the spatial distribution of the selected markets. The 'rings' of market days in the study area was also displayed graphically and the results are presented in the section that follows.

\section{RESULTS AND DISCUSSION \\ Features/Characteristics of Periodic Markets}

Periodic markets do not only serve as centres for the exchange of goods, ideas, fashions and provision of services, but also perform significant social and political functions in the community. They serve as meeting points for political campaigns, distribution of handbills from the new generation churches and advertising of new products/innovations. A typical market day starts at $5.30 \mathrm{am}$. The villagers arrive first with their farm produce carried on their heads. This is closely followed by long distance traders, itinerant traders and by 9.30 am the market is filled to capacity. The service providers arrive late-11am The mode of transport differs, depending on the range of goods and distance They include lorries, pick-up, buses, motorcycles and sometimes bicycles

As in other parts of the country, the periodic markets in the study area consists of a few permanent stores-lock-up, ,permanent shelter and open spaces where traders often squat behind their baskets of food stuff and other items taking shade normally from trees or temporary shelters made from branches and grass thatch.

The agro-based produce displayed in each market reflects the major ecological zones of the state and the range of agricultural produce/goods varies, depending on seasons and ecological zone.

\section{Market Periodicity and Movement of Itinerant Traders \\ A total of 18 traditional markets were} identified in 7 local government areas of the state (viz; Nsit Ibom, Itu, Etinan, Ikot Abasi, Uruan, Eket and Essien Udim LGAs) and each of the selected markets has a specific traditional market day, arranged in an eight day market cycle. The eight traditional market days are as follows;
a) Etaha
b) Edem etaha
c) Fiong etok
d) Edere obo
e) Obo
f) Edem obo
g) Fiongaran
h) Edere etaha

Typical eight- day and four-day cycles as revealed from interview with the itinerant traders are illustrated in figs. 2 and 3. 


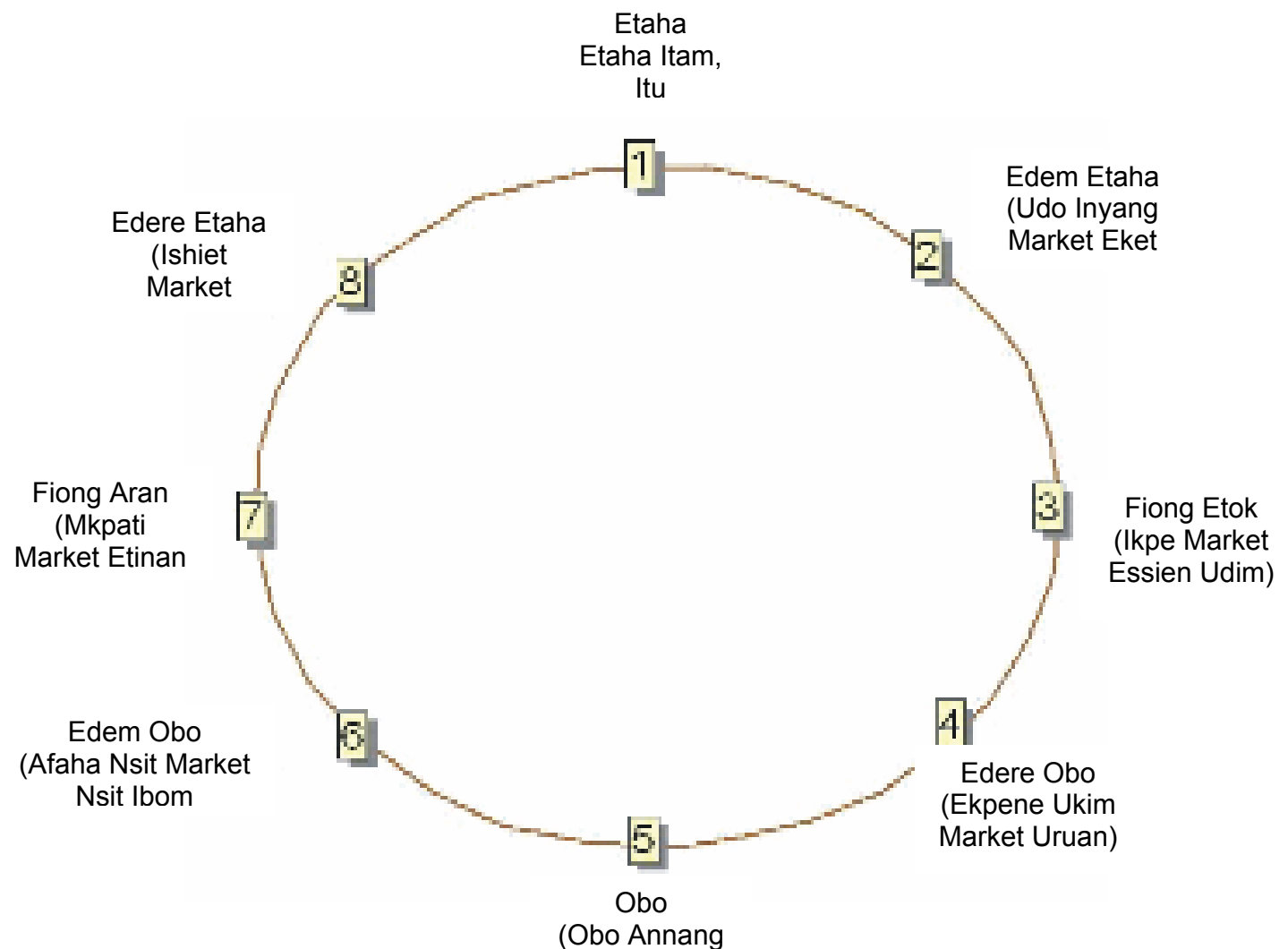

Essien Udim

Fig. 2 The Eight- Day Cycle in Akwa Ibom State

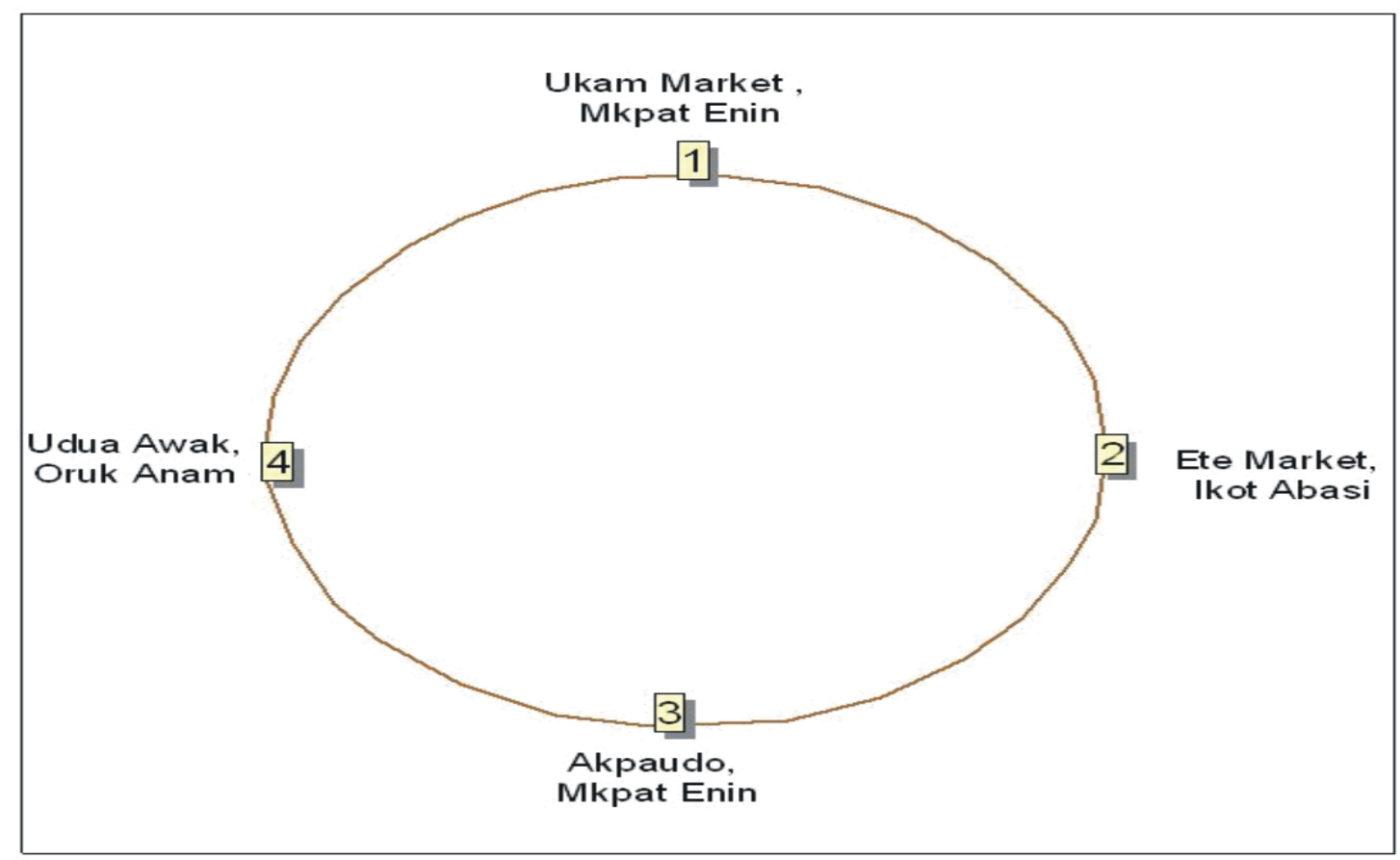

Fig. 3 The Four -Day Cycle, southwest of Uyo 
Although, there may be slight variations in the nomenclature of the traditional market days in Etinan, and the Annang -speaking LGAs in the state e.g in Etinan the following are the market days - Obo, Uruabm, Fiongaran, Ederitaha, Ataetaha, Uruaket, Fiongetok and Ederobo[fig.4].

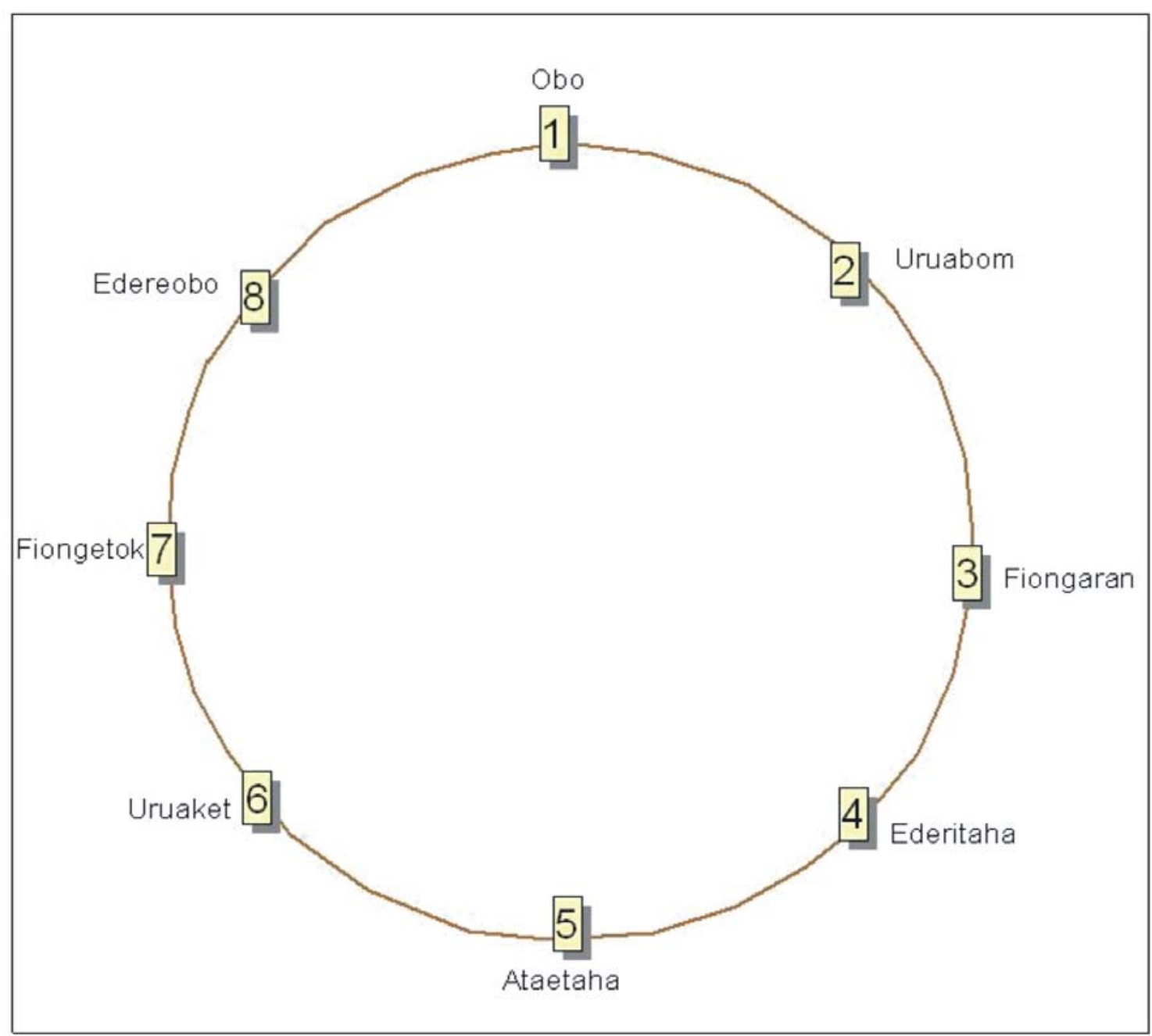

Fig.4 Market Periodicity in Etinan LGA, south of Uyo

Temporal Patterns and Movement of Itinerant Traders

These market days operate on a ring system and it is possible to match with modern calendar, once you identify a date with any traditional market day. Most often if a market day falls on a Sunday in the modern calendar, then that market will either hold on the Saturday prior or the following Monday depending on the decision of the particular market council. 
Table 1: Periodicity of Some Traditional Markets in the State

\begin{tabular}{|c|c|c|c|c|}
\hline $\mathrm{S} / \mathrm{N}$ & Market day & Name of markets & $\begin{array}{l}\text { Local Government } \\
\text { Area }\end{array}$ & $\begin{array}{l}\text { Distance from } \\
\text { Uyo[Km] }\end{array}$ \\
\hline 1 & Edere etaha & $\begin{array}{l}\text { Itu market } \\
\text { Ishiet market }\end{array}$ & $\begin{array}{l}\text { Itu } \\
\text { Uruan }\end{array}$ & $\begin{array}{l}25 \\
25\end{array}$ \\
\hline 2 & Etaha & Etaha Itam market & Itu & 3.05 \\
\hline 3 & Edem etaha & Udoinyang market & Eket & 42 \\
\hline 4 & Fiong etok & $\begin{array}{l}\text { Ikpe Annang } \\
\text { Fiong Etok market }\end{array}$ & $\begin{array}{l}\text { Essien Udim } \\
\text { Eket }\end{array}$ & $\begin{array}{l}17.5 \\
57.5\end{array}$ \\
\hline 5 & Edere obo & $\begin{array}{l}\text { Ekpene Ukim } \\
\text { Etinan market }\end{array}$ & $\begin{array}{l}\text { Uruan } \\
\text { Etinan }\end{array}$ & $\begin{array}{l}17.6 \\
27.5\end{array}$ \\
\hline 6 & Obo & Obo Annang market & Essien Udim & 45.01 \\
\hline 7 & Edem obo & $\begin{array}{l}\text { Urua Sam } \\
\text { Afaha Nsit market }\end{array}$ & $\begin{array}{l}\text { Essien Udim } \\
\text { Nsit Ibom }\end{array}$ & $\begin{array}{l}55.4 \\
22.1 \\
\end{array}$ \\
\hline 8 & Fiong aran & $\begin{array}{l}\text { Mkpafi market } \\
\text { Nung Udoe market }\end{array}$ & $\begin{array}{l}\text { Etinan } \\
\text { Ibesikpo }\end{array}$ & $\begin{array}{l}15.4 \\
15.0\end{array}$ \\
\hline
\end{tabular}

Source: Field survey, 2008

A trader residing in Uyo, for instance may visit an average of four markets in a week. This translates to a minimum distance of $100 \mathrm{kms}$, depending on the permutations [see table 1]. If for instance he visits all the markets in fig. 3 , then the average distance covered in a week is about $400 \mathrm{kms}$. The cost of traversing this distance will be built into the unit price of goods. On the other hand, another trader that visits Ishiet market[Uruan LGA]; Etaha itam(Itu LGA); Ikpe Annang(Essien Udim LGA) and Mkpafi market(EtinanLGA) in Edere etaha, Etaha, Fiong etok and Fiong aran respectively would have covered a total of $121.9 \mathrm{kms}$. The objective of any trader would always be to find the least-cost set of periodic market in terms of distance traveled (Good,1975). Mobile traders may choose to attend only those markets perceived to be potentially the most profitable, or may select only familiar markets as opposed those located in unfamiliar or hostile setting. In recent times a trend whereby wealthy traders relocate to lock-up shops in the neighbourhood of the long standing markets such as Etaha Itam, Ekpene Ukim and Ete markets was observed during field survey. These set of traders now engage the services of people to commute between the traditional markets on market days either as salaried workers or on commission basis. They deal mainly on manufactured goods, household items such as plastics materials, cosmetics, belts, stoves, cooking utensils, umbrella, clothing(both new and used) etc.

Origin of Selected Markets in the Study Area

As it is now, some of the traditional markets are named after the market days, for instance, Etaha Itam and Obo Annang markets in Itu and Essien Udim LGAs respectively. Although there are exceptions, for instance the periodic market at Ikot Nkan, Etinan LGA derives its name from a rich and charitable woman named Mkpafi who first started cooking and serving food to people in the neighbourhood of the present site of Mkpafi market. With time, people were attracted to establish other businesses and agglomerate around her shade for the purpose of exchange of goods and services and eventually it grew into a market site along the Uyo-Etinan road. Before now, the market covered the two sides of the road but the construction of tarred road led to increase in vehicular traffic and consequently high rates of accidents near the market. This prompted the village/market council to relocate the market to one side of the road. However, in most locations, markets are established by village councils, clan heads, paramount rulers(as in Etinan and $T$ junction markets)or by the local government councils.

The spatial pattern of the traditional markets is illustrated in fig. 5 . 

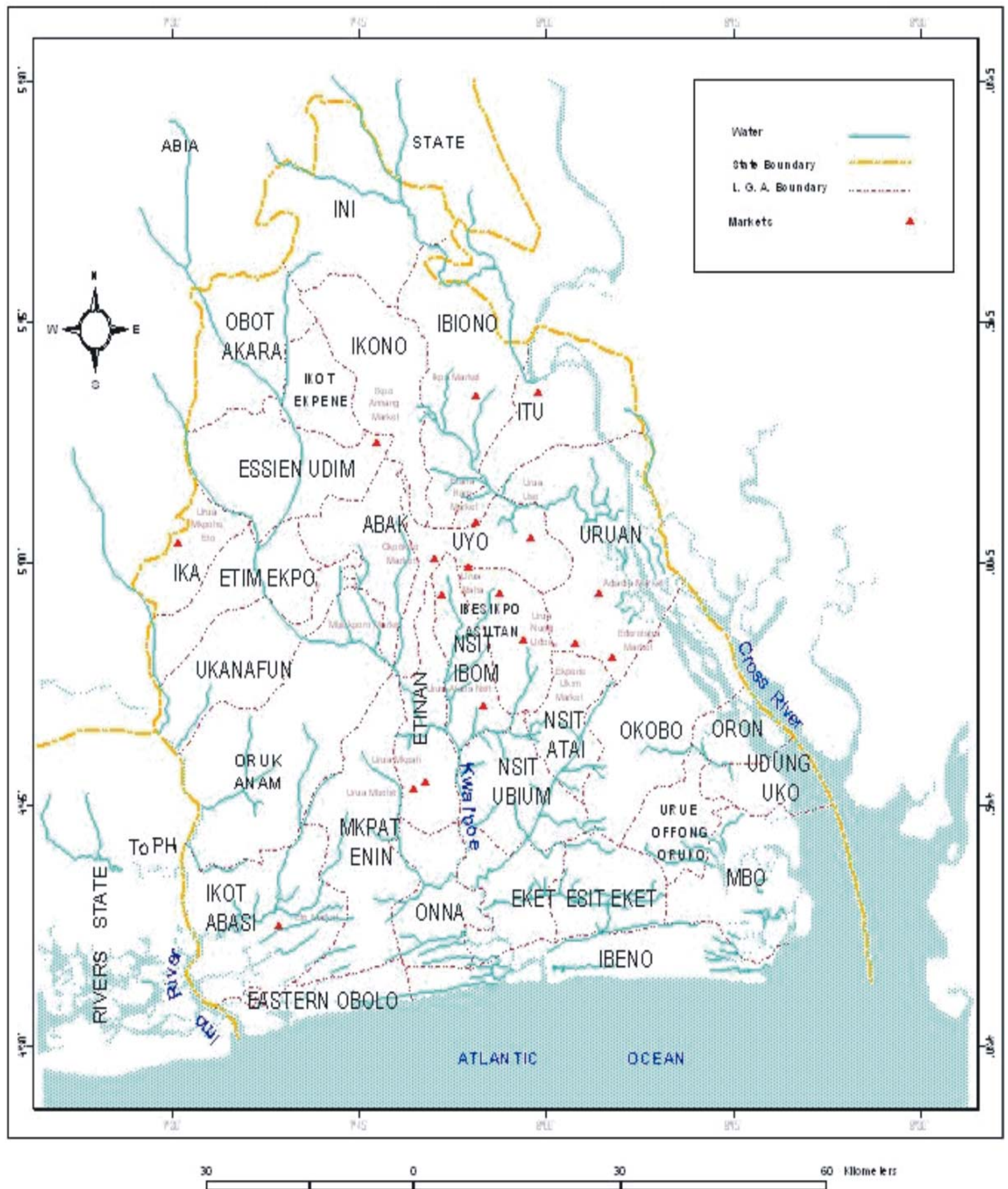

60 Klbme krs

Fig 5: Location of Selected Market in Akwa Ibom State 
Table 2: Selected Markets and the Traditional Market Days

\begin{tabular}{|c|c|c|c|c|c|c|c|c|}
\hline $\begin{array}{l}\text { Market } \\
\text { Name }\end{array}$ & Etaha & $\begin{array}{l}\text { Edem } \\
\text { Etaha }\end{array}$ & $\begin{array}{l}\text { Fiog } \\
\text { etok }\end{array}$ & $\begin{array}{l}\text { Edere } \\
\text { Obo }\end{array}$ & Obo & $\begin{array}{l}\text { Edem } \\
\text { obo }\end{array}$ & $\begin{array}{l}\text { Fiog } \\
\text { aran }\end{array}$ & $\begin{array}{l}\text { Edere } \\
\text { etaha }\end{array}$ \\
\hline $\begin{array}{l}\text { Ekpene } \\
\text { Ukim mkt }\end{array}$ & & & & $* *$ & & & & \\
\hline $\begin{array}{l}\text { Urua } \\
\text { Use }\end{array}$ & 4 day cycle & & & & & & & \\
\hline $\begin{array}{l}\text { Mbierebe } \\
\text { Obio mkt }\end{array}$ & * & & & $* *$ & & ** & & \\
\hline $\begin{array}{l}\text { Etaha } \\
\text { Itam mkt }\end{array}$ & ** & & & & & & & \\
\hline $\begin{array}{l}\text { Nung } \\
\text { Udoe mkt }\end{array}$ & Once/week & & & & & & & \\
\hline Urua Afaha Nsit & & & & ** & & & & \\
\hline Urua Anwa Afaha & & & ** & & & & & \\
\hline Mkpoho Eto & 3 day cycle & & & & & & & \\
\hline Ikpa market & ** & & & & & & & \\
\hline Edemetaha mkt,Uruan & & & $* *$ & & & & & \\
\hline Mkpafi mkt & & & & & & & ** & \\
\hline Ikpe Annang & & & $* *$ & & & & & \\
\hline Mbiokporo 1 & & & & & & & ** & \\
\hline T-Junction mkt & 4-day cycle & & & & & & & \\
\hline Okpokpo mkt & & & * & & & & * & \\
\hline Adadia Beach mkt & Mondays alone & & & & & & & \\
\hline Urua Mbehe Etinan & & & & ** & & & & \\
\hline Ete mkt lkot Abasi & & & * & & & & & * \\
\hline
\end{tabular}

* minor market day ** major market day

Source: Data Analysis, 2008

It is quite evident from table 2 that eight day markets are common in the study area (56\% of selected markets) It cuts across six local government areas viz: Itu, Eket, Essien Udim, Uruan, Nsit Ibom and Etinan.

Table 3: Market Cycles in selected LGAs in Akwa Ibom

\begin{tabular}{|l|l|l|l|}
\hline Market cycle & Frequency & Percentage & Locations \\
\hline 4 days & 5 & $27.5 \%$ & Uyo, Itu and Ikot Abasi \\
\hline Weekly & 2 & $11 \%$ & Uruan, Ibesipo Asutan \\
\hline 8 day cycle & 10 & $56 \%$ & Itu, Essien Udim, Etinan, Uruan, Nsit Ibom, Eket \\
\hline 3 day cycle & 1 & $5.5 \%$ & Etinan \\
\hline
\end{tabular}


The four day market system was also found in the study area, as shown in fig. 3. Often, two to three of the market days are major markets while the last may be a minor market day and the traveling traders (especially lbos) do not attend the minor market days. The weekly and three day cycle is rare in the study area $(11 \%$ and $5.5 \%$ respectively).

In a related study of seventeen periodic markets in east Buganda, Mubende and west Buganda districts in Uganda, Good(1975) observed that the periodicity was largely 7- day cycle, 14 and 28 day cycles And that the number of market visits ranged from ten to twenty-four in a month.

The pattern reported by Good (1975) and the present study contrasts sharply with the observation by Nwafor (1982) that 'four day markets are common in Yorubaland, while the seven-day(presumably of Islamic origin) dominates the northern part of the country'. Furthermore, he noted the existence of a number of 3-day markets in Katsina; 5-day markets in Tivland, Igala and Idoma and that the 2-day market cycle is rather uncommon in the country.

\section{CONCLUSION}

This study clearly shows that, periodic markets developed due to a low density of demand for goods. These types of markets concentrate sales into a short time period, favouring the areas that are most accessible, e.g near the major roads or market squares often located near the palace of the traditional rulers in rural settlements. Periodic markets in the study have been shown to reduce the distance that a buyer must travel to obtain required goods and services. Periodic markets are also advantageous because in the hinterland of Akwa Ibom State they permit the dense distribution of market-towns which serve the spatially distanced villages, instead of allowing only a few towns to have markets and forcing the rest of the population to commute. More importantly, they are the bulk- building points of palm kernel, palm oil and local crafts as well as sources of foodstuff to the ever increasing population in our major urban centres, particularly Uyo, the state capital.

In conclusion, further research is recommended to ascertain the traditional market days and cycles of market days in the food producing communities of northern Cross River State. This information will be useful to public transport operators as well as ensuring food security in the urban centres of Akwa Ibom State.

\section{ACKNOWLEDGEMENT}

I am appreciative of the cooperation and support from my students who participated in the field survey.

\section{REFERENCES}

Bromley, R. J., 1971. 'Markets in the Developing Countries; A Review'. Geography 56: pp.124-132

Daniel, Ekong E., 2004. Digital Mapping of Markets Distributions': A case Of Akwa lbom State, Nigeria. In R.E. Ekpeyong and Nnabugwu Uluocha: Cartography , GIS and Agricultural Development, Abaam Nigeria.

Filani, M. O. and Richards P., 1976. 'Periodic Market Systems and Rural Development: the Ibarapa case study, Nigeria. Savanna 5: pp. 149-62.

Good, C. M., 1975. Periodic markets and traveling traders in Uganda' The Geographical Review .pp.49-72

Hay, A.M., 1971. Notes on the Economic Basis for Periodic Marketing in Developing Countries' Geographical Analysis 3: pp.393 -400

Hodder, B. W., 1961. "Rural Periodic Day Markets in Part of Yoruba land." Transaction of the Institute of British Geographers. (Old Series), 36:149-159.

Mckim, W., 1972. 'The Periodic Market System in North-eastern Ghana' Economic Geography, 48: pp.333-344

Nwafor, J., 1982. 'Marketing system and periodic markets' in Barbour, K.M.,Oguntoyinbo J.S. Onyemelukwe, J.O.C. and Nwafor, J.C. [eds] Nigeria in Maps Hodder and Stoughton, London. pp.114

Scott, E.P., 1972. 'The Spatial Structure of Rural Northern Nigeria; Farmers, Periodic Markets and Villages' Economic Geography, 48; pp 316-332.

Skinner, G. W., 1964. "Marketing and Social Structure in Rural China." Journal of Stan Studies, 24:3-43. 
Stine, J. H., 1962. "Temporal Aspects of Tertiary Production Elements in Korea ." in F.R. Pitts, ea., Urban Systems and Economic Development. University of Oregon Press. Eugene, Oregon.

Udosen, C. E., 2008. Gully Erosion in Ikpa River Basin: A threshold phenomenon Time Communication, Lagos

Webber, M. J. and Symanski, R., 1973. 'Periodic Markets : An economic Location Analysis'. Economic Geographer' 49: pp. 213 - 227 